\title{
Photosynthesis in Mesodinium rubrum: species- specific measurements and comparison to community rates
}

\author{
Diane K. Stoecker ${ }^{1, *}$, Mary Putt ${ }^{2}$, Linda H. Davis ${ }^{1}$, Ann E. Michaels ${ }^{1}$ \\ ${ }^{1}$ Biology Department, Woods Hole Oceanographic Institution, Woods Hole, Massachusetts 02543, USA \\ ${ }^{2}$ Oceanography Department, Old Dominion University, Norfolk, Virginia 23529-0276, USA
}

\begin{abstract}
The photosynthetic ciliate Mesodinium rubrum is a common component of the plankton in estuarine, coastal and offshore areas. Unusually high photosynthetic rates $\left[\geq 10 \mathrm{pg} \mathrm{C}(\mathrm{pg} \mathrm{chl} \mathrm{a})^{-1} \mathrm{~h}^{-1}\right]$ have been measured during visible blooms (red-waters) of this species, but little data were available on photosynthesis by Mesodinium during more routine conditions. We used single cell techniques to measure chlorophyll content and rates of photosynthesis in Mesodinium (16 to $18 \times 21$ to $22 \mu \mathrm{m}$ in size) that were part of mixed-species phytoplankton assemblages in small estuaries and salt ponds. The carbon:chlorophyll a (wt:wt) ratio for Mesodinium ranged from 47 to 78 . Light-saturated rates of photosynthesis ranged from 13 to $88 \mathrm{pg} \mathrm{C}$ cell $^{-1} \mathrm{~h}^{-1}\left[1.8\right.$ to $\left.8.6 \mathrm{pg} \mathrm{C}(\mathrm{pg} \mathrm{chl} \mathrm{a})^{-1} \mathrm{~h}^{-1}\right]$. These speciesspecific assimilation ratios were within the mid-range reported for community measurements made during Mesodinium red-waters and within the range reported for phytoplankton. $I_{k}$ values for Mesodinium were $\geq 275 \mu \mathrm{E} \mathrm{m} \mathrm{m}^{-2} \mathrm{~s}^{-1}$ in all experiments. At saturating irradiance, carbon fixation ranged up to ca $14 \%$ of body $\mathrm{C} \mathrm{h}^{-1}$ In our incubations, Mesodinium accounted for from $<1$ to $\geq 70 \%$ of the community primary production in surface water samples although at no time during our studies did it cause red-waters.
\end{abstract}

\section{INTRODUCTION}

Mesodinium rubrum (Lohmann) Hamburger \& Buddenbrock (hereafter Mesodinium) is a marine planktonic ciliate with a reduced cryptophyte endosymbiont. This ciliate is functionally a part of the phytoplankton assemblage (Parsons \& Blackbourn 1968, Taylor et al. 1971, Lindholm 1985, Crawford 1989). Occasionally $M$. rubrum forms non-toxic red-water blooms in estuaries, fjords and in ocean upwelling areas. However, this species occurs routinely at lower densities as part of mixed microplankton assemblages in both temperate and polar regions (Gieskes \& Kraay 1983, Lindholm 1985, Crawford 1989, Montagnes \& Lynn 1989, Stoecker et al. 1989, Putt 1990b, Putt \& Stoecker unpubl.).

During red-water conditions, Mesodinium can reach densities of over $10^{6}$ cells $\mathrm{l}^{-1}$ (Lindholm 1985). Unusually high chlorophyll a concentrations $\left(>100 \mu \mathrm{g} \mathrm{l}^{-1}\right)$

\footnotetext{
- Present address: Horn Point Environmental Laboratories, PO Box 775, Cambridge, Maryland 21613-0775, USA
}

and rates of primary production $\left(>500 \mu \mathrm{g} \mathrm{C} \mathrm{l}^{-1} \mathrm{~h}^{-1}\right.$ ) have been reported in association with Mesodinium blooms (reviewed in Lindholm 1985). Assimilation rates at saturating light intensities (i.e. maximum chlorophyll-specific rates of photosynthesis) $\geq 10 \mu \mathrm{g} \mathrm{C}$ ( $\mu \mathrm{g}$ chl $a)^{-1} \mathrm{~h}^{-1}$ have been measured during Mesodinium blooms in upwelling areas (Smith \& Barber 1979, Cabeçadas et al. 1983). However, because these measurements were made on whole water samples, they include an unquantified contribution from algae and cyanobacteria. For some phytoplankters, species-specific data on photosynthetic physiology are available from laboratory experiments using cultures (i.e. Glover 1980). Mesodinium has not been cultured, therefore laboratory data on its physiology are not available.

Cell-based estimates are necessary in order to estimate the contribution of this ciliate to total chlorophyll and community photosynthesis during both red-water and more routine conditions and to understand its physiological ecology and population dynamics.

In order to better characterize the photosynthetic 
physiology of Mesodinium and to evaluate its contribution to primary production in coastal waters during nonred-water conditions, we used single cell techniques to estimate the carbon content, chlorophyll a content and photosynthetic rate of this ciliate when present at densities well below those that cause red-waters.

\section{METHOD AND MATERIALS}

Sample collection and enumeration of Mesodinium. Experiments were conducted during 3 periods when Mesodinium rubrum was abundant in estuaries in Falmouth, Massachusetts, USA (Table 1). During these times, Mesodinium densities were between $10^{4}$ and $2 \times 10^{5}$ cells $1^{-1}$, somewhat higher than the range typical for temperate waters $\left(10^{2}\right.$ to $\left.10^{4} \mathrm{I}^{-1}\right)$ but well below the densities reported during red-waters (generally

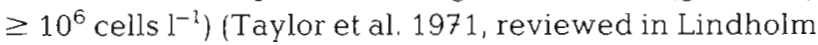
1985, Montagnes \& Lynn 1989). The experiments were done when densities were high, because at lower densities it would not be feasible to do the large number of single cell isolations required by the experimental protocols described below.

On the days of the experiments, surface water samples were collected from Perch Pond or Salt Pond, 2 small estuaries in Falmouth, between $07: 30 \mathrm{~h}$ and 09:00 $\mathrm{h}$ and transported to the laboratory. The in situ temperature was measured.

In the laboratory, $50 \mathrm{ml}$ subsamples were fixed in $2 \%$ acid Lugol's solution for enumeration of Mesodinium using the inverted microscope method (Hasle 1978). Cell size was measured with an ocular micrometer and cell volumes calculated using an oblate spheroid approximation of cell shape. Cell carbon was calculated from cell volume using a conversion factor of $0.19 \mathrm{pg} \mathrm{C} \mathrm{mm}^{-3}$. This factor was experimentally derived for 'oligotrichous' ciliates fixed in $2 \%$ acid Lugol's solution (Putt \& Stoecker 1989); preliminary data suggest that the conversion factor for Mesodinium might be slightly lower than 0.19 (Putt unpubl.) but well above the factor $(0.11)$ that has been recommended for unarmoured phytoplankton and most ciliates (Edler 1979).

Chlorophyll determinations. For the determination of total and microplankton chlorophyll, water samples were filtered either directly, or after passage through a $20 \mu \mathrm{m}$ nitex mesh onto a GF/F filter (Whatman). For the determination of Mesodinium chlorophyll, individual cells were isolated under a dissecting microscope, washed with sterile seawater medium (Stoecker et al. 1988 ) and transferred onto GF/F filters (40 cells per replicate filter). Blank filters were prepared using similar amounts of wash water.

In Expt I, a drop of saturated EDTA solution was added to a 15 to $20 \mathrm{ml}$ sample to slow ciliates (Lindholm 1982) during isolations. In Expts II and III, the Mesodinium were concentrated prior to isolation using Percoll (Price et al. 1978). Seawater samples (30 ml) were layered over chilled $90 \%$ Percoll-sorbitol seawater and centrifuged at $110 \times \mathrm{g}$ for $10 \mathrm{~min}$ at $10^{\circ} \mathrm{C}$ in a swinging bucket rotor. Water at the seawater and Percoll-sorbitol interface was enriched with $\mathrm{Me}$ sodinium and was used for the initial single cell isolations.

All GF/F filters were extracted with $90 \%$ acetone at $-20^{\circ} \mathrm{C}$ for $24 \mathrm{~h}$ prior to fluorometric determination of chlorophyll. Microplankton chlorophyll was determined by subtraction of the $<20 \mu \mathrm{m}$ chlorophyll from total chlorophyll. Blank values were subtracted from chlorophyll determinations in Mesodinium.

${ }^{14} \mathrm{C}$ uptake experiments. Photosynthesis-irradiance (P-I) relationships were determined for the community and for Mesodinium in an outdoor incubation in Expt I and in a photosynthetron (Prézelin et al. 1986) in Expts II and III. All incubations commenced within $4 \mathrm{~h}$ of sample collection and were at temperatures within $2{ }^{\circ} \mathrm{C}$ of ambient water temperatures. ${ }^{14} \mathrm{C}$-bicarbonate (final activity ca $0.5 \mu \mathrm{Ci} \mathrm{ml} l^{-1}$ ) was added to the water sample and subsamples taken for determination of specific activity (Stoecker et al. 1988). The water sample was then split into $30 \mathrm{ml}$ aliquots and incubated for 1.75 to $2 \mathrm{~h}$ at irradiances between 0 and $100 \%$ of incident in Expt I and between 0 and $500 \mu E \mathrm{~m}^{-2} \mathrm{~s}^{-1}$ in Expts II and

Table 1. Dates and location of sample collection for Mesodinium rubrum experiments. Means \pm standard error of mean. $N=$ sample size

\begin{tabular}{|c|c|c|c|c|c|c|}
\hline $\begin{array}{l}\text { Expt } \\
\text { no. }\end{array}$ & Date & Location & $\begin{array}{c}\text { Water temp. } \\
\left({ }^{\circ} \mathrm{C}\right)\end{array}$ & $\begin{array}{c}\text { Salınity } \\
(\% 0)\end{array}$ & $\begin{array}{c}\text { Total chl a } \\
\left(\mu \mathrm{g} \mathrm{l}^{-1}\right)\end{array}$ & $\begin{array}{l}\text { Mesodinium } \\
\left(\text { cells } 1^{-1}\right)\end{array}$ \\
\hline I & 16 Jun 1988 & Perch Pond & 22 & 24 & $\begin{array}{c}29.0 \pm 00 \\
(\mathrm{~N}=: 2)\end{array}$ & $10.5 \times 10^{3}$ \\
\hline II & 9 Jun 1989 & Salt Pond & 19 & 20 & $\begin{array}{c}7.45=0.85 \\
(N=5)\end{array}$ & $186.0 \times 10^{3}$ \\
\hline III & 6 Oct 1989 & Perch Pond & 15 & 12 & $\begin{array}{c}1.02 \pm 0.24 \\
(\mathrm{~N}=2)\end{array}$ & $113.0 \times 10^{3}$ \\
\hline
\end{tabular}


III. Irradiance was determined using a Li-Cor Quantum Photometer (model Li-185 B equipped with a spherical sensor).

For the determination of community photosynthesis, $2 \mathrm{ml}$ subsamples were removed from each aliquot immediately after the incubation and placed in scintillation vials. For determination of Mesodinium photosynthesis, individual ciliates were isolated, washed 2 or 3 times in sterile media, and transferred (10 cells per vial) into scintillation vials. During the 1 to $2 \mathrm{~h}$ period when the single cell isolations were carried out, samples were maintained in the dark on ice. All samples were acidified with $5 \%$ acetic acid in methanol to remove inorganic carbon and processed as previously described (Stoecker et al. 1988). For both community and single species measurements, radioactivity in samples incubated in the dark (controls) was subtracted from values in the light.

P-I calculations. Photosynthesis was calculated using dissolved carbon values determined from carbonate alkalinity (Parsons et al. 1984). The model

$$
P=P \max \tanh (\alpha I / P \max )
$$

where $P=$ photosynthetic rate measured at some irradiance $(I), P \max =$ light-saturated photosynthetic rate, and $\alpha=$ slope of the light-limited region of the P-I curve, was fit to the P-I data using Powell's least square method (Jassby \& Platt 1976, Press et al. 1988). $I_{k}$ values were determined as:

$$
I_{k}=P \max / \alpha
$$

The standard error (SE) of the curve fit was estimated from

$$
\mathrm{SE}=\left[\sum i / n\right]^{0.5}
$$

where $\Sigma i=$ sum of the residuals, and $n=$ number of $\mathrm{P}-\mathrm{I}$ pairs. Parameter values reported were determined from the hyperbolic tangent model. However, the curve fit procedure does not give independent errors for the fit of the model to Pmax and $\alpha$. In order to estimate the error associated with the light-limited portion of the curve, $\alpha$ values and the associated error were recalculated using a linear model for the P-I pairs below the $I_{k}$ value (Zar 1974). $\alpha$ values determined from the linear and hyperbolic tangent models agreed to within $20 \%$ except as noted.

\section{RESULTS}

Two incubations were conducted in June and one in October. Temperature, salinity and chlorophyll levels varied considerably among experiments (Table 1). Mesodinium densities ranged from a low of about $10^{4}$ $\mathrm{I}^{-1}$ in Expt I (16 June 1988) to about $2 \times 10^{5} \mathrm{I}^{-1}$ in Expt II (9 June 1989) (Table 1). In all the experiments, the Mesodinium were small cells (16 to 17 by 21 to $22 \mu \mathrm{m}$ when fixed in $2 \%$ acid Lugol's solution) with volumes between about 2800 and $3600 \mathrm{~mm}^{3}$ cell $^{-1}$ (Table 2). Average chiorophyll contents per cell varied from 7.4 to $13.3 \mathrm{pg}$ and calculated $\mathrm{C}: \mathrm{chl}$ a ratios from 47 to 78 (Table 2).

Photosynthetic parameters for Mesodinium varied among experiments. In Expts $I$ and III the assimilation ratio for Mesodinium was high, 8.6 and $6.6 \mu \mathrm{g} \mathrm{C}(\mu \mathrm{g} \mathrm{chl}$ a) $)^{-1} \mathrm{~h}^{-1}$ respectively, $\alpha$ values were over $0.02 \mu \mathrm{g} C$ ( $\mathrm{gg}$ chl $a)^{-1} \mathrm{~h}^{-1}\left(\mu \mathrm{E} \mathrm{m} \mathrm{m}^{-2} \mathrm{~s}^{-1}\right)^{-1}$, and the onset of light-saturation $\left(I_{k}\right)$ was at irradiances of $\geq 275 \mu \mathrm{E} \mathrm{m} \mathrm{m}^{-2} \mathrm{~s}^{-1}$ (Figs. $1 \&$ 2b; Table 3). In contrast, in Expt II the assimilation ratio was low (1.8), $\alpha$ values were considerably lower, and photosynthesis did not saturate below $450 \mu \mathrm{E} \mathrm{m}^{-2} \mathrm{~s}^{-1}$ (Fig. 2a; Table 3).

In Expt I, the chlorophyll-specific rates of photosynthesis were higher in Mesodinium than in the assemblage as a whole at irradiances over $100 \mu \mathrm{E} \mathrm{m}^{-2} \mathrm{~s}^{-1}$ but not at lower irradiances (Fig. 1; Table 3). In Expt II, chlorophyll-specific rates of photosynthesis in Mesodinium were lower than in the whole water (Fig. 2a; Table 3). In Expt III, in which Mesodinium was the

\begin{tabular}{|c|c|c|c|c|c|c|}
\hline $\begin{array}{l}\text { Expt } \\
\text { no. }\end{array}$ & $\begin{array}{l}\text { Cell dimensions } \\
\qquad(\mu \mathrm{m})\end{array}$ & $\begin{array}{l}\text { Approx. } \\
\text { cell vol. } \\
\left(\mu \mathrm{m}^{3}\right)\end{array}$ & $\begin{array}{c}\text { Approx. carbon } \\
\text { content }^{b} \\
\left(p g \text { cell }^{-1}\right)\end{array}$ & $\begin{array}{r}\text { Ch } \\
\left(\text { pg cell }{ }^{-1}\right)\end{array}$ & $\left(\mathrm{fg} \mu \mathrm{m}^{-3}\right)$ & C: chl a \\
\hline I & $\begin{array}{l}18 \times 22 \\
(N=5)\end{array}$ & $3606 \pm 238$ & -685 & $8.8 \pm 0.5$ & $\sim 2.4$ & 78 \\
\hline II & $\begin{array}{c}16 \times 21 \\
(\mathrm{~N}=11)\end{array}$ & $2852 \pm 394$ & $\sim 542$ & $7.4 \pm 1.8$ & -2.6 & 73 \\
\hline III & $\begin{array}{c}17 \times 22 \\
(\mathrm{~N}=30)\end{array}$ & $3267 \pm 143$ & $\sim 621$ & $13.3 \pm 2.0$ & $\sim 4.1$ & 47 \\
\hline
\end{tabular}
dominant phytoplankter, chlorophyll-specific rates of

Table 2. Mesodinium rubrum. Size, carbon and chlorophyll content. Means \pm standard error of mean. $N=$ sample size 


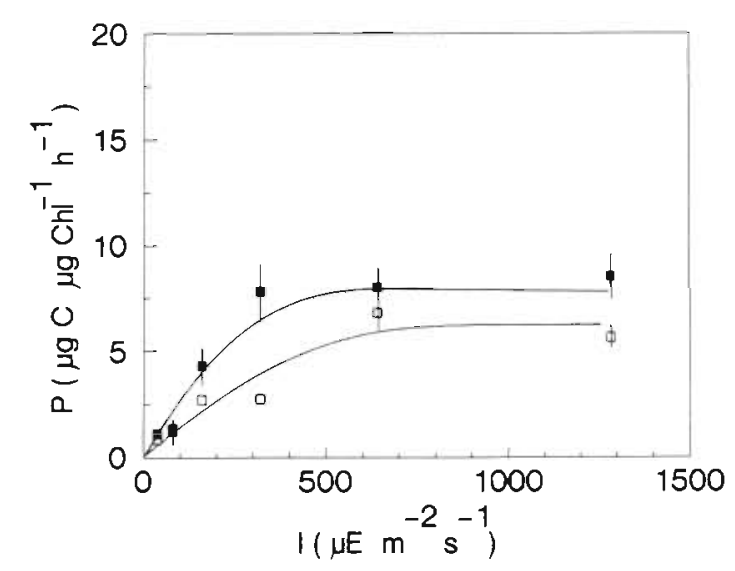

Fig. 1. Photosynthesis-irradiance (P-I) curves for Mesodinium rubrum (ब) and whole water samples ( $(\sigma)$; Expt I, water collected 16 June 1988 from Perch Pond. Incubation in an outdoor raceway. Means \pm standard error of the mean $(N=3)$ for Mesodinium and range of duplicates for whole water samples. Where no error bar is shown, the error was smaller than the symbol

photosynthesis appeared to be lower in Mesodinium than in the assemblage as a whole.

Variation in per cell rate of photosynthesis paralleled the variation in assimilation ratio among experiments (Tables 3 \& 4). Light-saturated rates of photosynthesis per Mesodinium cell were between 75 and $88 \mathrm{pg} \mathrm{C} \mathrm{h}^{-1}$ in Expts I and III. Based on the estimated carbon content cell ${ }^{-1}$ (Table 2), carbon-specific rates in Expts I and III were ca $11 \%$ and $14 \%$ of body $\mathrm{C} \mathrm{h}^{-1}$ (Table 4 ). In Expt II, per-cell rates and carbon-specific rates were $<20 \%$ of those observed in Expts I and III (Table 4 ).

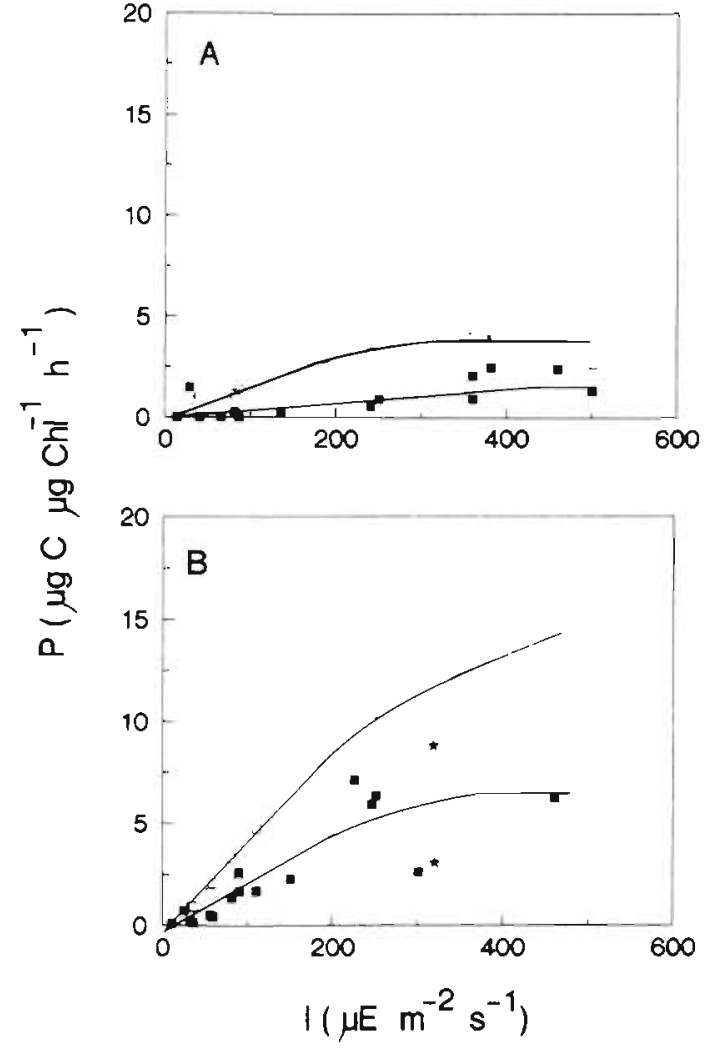

Fig. 2. Photosynthesis-irradiance (P-I) curves for Mesodinium rubrum (a) and whole water samples ( $\square$ ). Incubations in a photosynthetron. (A) Expt II, 9 June 1989, water collected from Salt Pond. (B) Expt III, 6 October 1989, water collected from Perch Pond. $(\star)$ M. rubrum cells in this replicate appeared to be dying. Data from this replicate were not included in the calculation of photosynthetic parameters

Table 3. Light-saturated photosynthesis ( $P \max$ ), slope of the light-saturated portion of the photosynthesis-irradiance curve $(\alpha)$ and $I_{k}$ values for Mesodinium rubrum (MESO) and whole water (WW) samples. Chlorophyll-based values. Statistics \pm standard error

\begin{tabular}{|c|c|c|c|c|}
\hline $\begin{array}{l}\text { Expt } \\
\text { no. }\end{array}$ & Date & 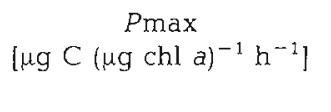 & $\begin{array}{c}\alpha \\
{\left[\mu \mathrm{g} \mathrm{C}(\mu \mathrm{gg} \mathrm{chl} a)^{-1} \mathrm{~h}^{-1}\right]} \\
\underset{\left(\mu \mathrm{E} \mathrm{m}^{-2} \mathrm{~s}^{-1}\right)^{-1}}{\mathrm{C}}\end{array}$ & $\begin{array}{c}I_{k} \\
\left(\mu \mathrm{E} \mathrm{m}^{-2} \mathrm{~s}^{-1}\right)\end{array}$ \\
\hline \multirow[t]{3}{*}{ I } & 16 Jun 1988 & & & \\
\hline & MESO & $8.6 \pm 1.9$ & $0.030 \pm 0.005$ & 287 \\
\hline & WW & $6.2 \pm 0.8$ & $\begin{array}{c}0.014 \pm 0.002 \\
(0.007)^{b}\end{array}$ & 443 \\
\hline \multirow[t]{3}{*}{ II } & 9 Jun 1989 & & & \\
\hline & MESO & $1.8^{a}$ & $0.004 \pm 0.001$ & 450 \\
\hline & WW & $4.2 \pm 0.6$ & $\begin{array}{c}0.017 \pm 0.004 \\
(0.009)^{\mathrm{b}}\end{array}$ & 247 \\
\hline \multirow[t]{3}{*}{ III } & 6 Oct 1989 & & & \\
\hline & MESO & $6.6 \pm 1.3$ & $0.024 \pm 0.002$ & 275 \\
\hline & WW & $N D^{c}$ & $0.039 \pm 0.003^{c}$ & $>460^{\circ}$ \\
\hline \multicolumn{5}{|c|}{$\begin{array}{l}{ }^{\mathrm{a}} \text { Curve fit program could not find assymptote. Pmax reported from mean of values } \geq 460 \mu \mathrm{E} \mathrm{m}^{-2} \mathrm{~s}^{-1} \\
{ }^{\mathrm{b}} \text { Linear model }\end{array}$} \\
\hline
\end{tabular}


Table 4. Mesodinium rubrum. Light-saturated photosynthesis (Pmax). Rates per cell, per unit volume, and as \% body carbon

\begin{tabular}{|c|c|c|c|}
\hline $\begin{array}{l}\text { Expt } \\
\text { no. }\end{array}$ & pg $C$ cell $^{-1} h^{-1}$ & $\operatorname{fg} C \mu \mathrm{m}^{-3} \mathrm{~h}^{-1}$ & $\begin{array}{c}\text { Body C } \\
\mathrm{h}^{-1}\end{array}$ \\
\hline I & $75 \pm 17^{a}$ & 20.8 & $11 \%$ \\
\hline II & $13^{b}$ & 4.6 & $2 \%$ \\
\hline III & $88 \pm 17$ & 26.9 & $14 \%$ \\
\hline \multicolumn{4}{|c|}{$\begin{array}{l}\text { a Standard error } \\
{ }^{b} \text { Curve fit program could not find an assymptote. Pmax } \\
\text { reported from mean of values } \geq 460 \mu \mathrm{E} \mathrm{m}^{-2} \mathrm{~s}^{-1}\end{array}$} \\
\hline
\end{tabular}

\section{DISCUSSION}

Mesodinium rubrum may represent a species complex; cells range in length from 10 to $70 \mu \mathrm{m}$ and size differs both seasonally and geographically. Large and small forms are often found sequentially (Montagnes \& Lynn 1989) or simultaneously (Taylor et al. 1971, Lindholm 1985. Crawford pers. comm.). The Mesodinium that we observed during June 1988 and 1989 and October 1989 in the estuaries were 21 to $22 \mu \mathrm{m}$ long (2800 to $3600 \mu^{3}$ in volume) and were similar in size to those observed during summer in the Gulf of Maine (Montagnes \& Lynn 1989). However, the cells we observed were considerably smaller than those usually observed by Lindholm \& Mörk (1990) in the Baltic and by Smith \& Barber (1979) in the Peru upwelling. This variation in size, and perhaps physiology, within the species complex should be considered when comparing or applying our results to other situations.

Within a population, physiology changes in response to environmental changes. Confinement and nutrient depletion can have an important influence on photosynthetic rates in Mesodinium (Smith \& Barber 1979. Wilkerson \& Grunseich 1990). Although Mesodinium is found year-round in local waters, its population peaks in the spring and fall in local estuaries. Blooms usually only last a few days. In our study, cellular and chlorophyll-specific photosynthetic rates were lower in Expt II than in Expts I and III (Tables 3 and 4). Expt II was done as a bloom was declining in Salt Pond whereas the other experiments were done when Mesodinium densities were increasing (Expt I) or just when Mesodinium numbers were peaking (Stoecker unpubl.). The lower rates in Expt II, when a bloom was declining, may reflect nutrient limitation or another stress.

The assimilation ratios (chlorophyll-specific Pmax) that we observed for Mesodinium (1.8 to 8.6) are within the range reported for water samples during Mesodinium red-waters in coastal upwelling off Portugal (Cabeçadas et al. 1983) and off Baja California
(Packard et al. 1978) but lower than assimilation ratios (9.4 to 16) reported during red-waters in the Peru upwelling (Smith \& Barber 1979, Platt et al. 1980). The assimilation ratios we observed are within the upper range of those observed in exponential-phase phytoplankton cultures (Glover 1980) and in natural plankton assemblages (Malone 1980, Platt et al. 1980).

The cellular rates we observed at saturating irradiance (13 to $88 \mathrm{pg} \mathrm{C} \mathrm{h}^{-1}$ ) are similar to the rate observed per cell $\left(85 \mathrm{pg} \mathrm{C} \mathrm{h}^{-1}\right.$ ) at $100 \mu \mathrm{E} \mathrm{m}^{-2} \mathrm{~s}^{-1}$ (presumably not a saturating irradiance) in Mesodinium on Georges Bank in summer (Stoecker et al. 1989), but the cells in the study on Georges Bank were considerably larger, 30 to $50 \mu \mathrm{m}$ in length (Stoecker unpubl.). In our incubations, photoinhibition of Mesodinium did not occur or was slight, however the highest irradiance achieved in Expts II and III was ca $500 \mu \mathrm{E} \mathrm{m}^{-2} \mathrm{~s}^{-1}$; photoinhibition may occur at higher irradiances than we achieved. $I_{k}$ values were high (Figs. 1 \& 2). Minimal photoinhibition, if any, and high $I_{k}$ values are typical of Mesodinium red-waters as well (Smith \& Barber 1979, Platt et al. 1980).

In Expt I and III, the carbon-specific photosynthetic rates at saturating irradiances were high, ca $11 \%$ and $14 \%$ of body $\mathrm{C} \mathrm{h}^{-1}$ (Table 4 ). The volume-to-carbon conversion factor that we used may overestimate body carbon for Mesodinium (see 'Method and materials') and thus our estimates of carbon-specific rates are actually conservative. The carbon-specific rates for Mesodinium in Expts I and III were within the range found in some bloom-forming microalgae. For example, we calculate that the bloom-forming red-water dinoflagellate Gonyaulax tamarensis has a carbonspecific $P \max$ as high as 7.5 to $15 \%$ cell $\mathrm{C} \mathrm{h}^{-1}$; this calculation is based on an observed $P \max$ of 0.15 to $0.30 \mathrm{ng} \mathrm{C}$ cell $^{-1} \mathrm{~h}^{-1}$ (Glibert et al. 1988) and a carbon content of $2 \mathrm{ng} \mathrm{cell}^{-1}$ (Watras et al. 1985).

In the chloroplast-retaining ciliates, ${ }^{14} \mathrm{C}$ uptake underestimates the total benefit of photosynthesis due to rapid carbon cycling within the ciliate-plastid system and/or preferential respiration of photosynthate over ingested carbon (Putt 1990a, Stoecker \& Michaels 1991). Because Mesodinium is essentially a photoautotroph, the effect of internal carbon flux on measurement of photosynthesis is probably less in this species than in the plastid-retaining species. In Mesodinium, photosynthate must be used for growth as well as to meet respiratory demands for carbon. Preliminary data suggest (Putt unpubl.) that in Mesodinium photosynthate is allocated to protein and polysaccharide pools; in contrast, in the chloroplast-retaining species, photosynthate is primarily shunted into polysaccharide pools and rapidly respired (Putt 1990a). In the chloroplastretaining ciliates the net gain from photosynthesis is in the range of 1.0 to $3.4 \%$ body carbon $h^{-1}$ at saturating 
irradiance for cultured cells (Stoecker \& Michaels 1991). In these species photosynthesis appears to spare body carbon derived from ingested food and thus the total benefit is in the range of 2.5 to $7.5 \%$, somewhat lower than the maximum gain in Mesodinium (Table 4).

The volume-specific chlorophyll content of $\mathrm{Me}$ sodinium 2.4 to $4.1 \mathrm{fg}_{\mu \mathrm{m}^{-3}}$, is within the range reported in algae of similar size (Fig. 12.2 in Malone 1980) and in the chloroplast-retaining ciliates (Stoecker et al. 1988/ 1989). The assimilation ratios (chlorophyll-specific $P$ max) in Expts I and III for Mesodinium were 6.6 and 8.6, respectively; higher than the assimilation ratios in chloroplast-retaining ciliates $(<1$ to about 4 ; Stoecker et al. 1988, Stoecker et al. 1988/1989, Putt 1990b). Carbon flux within these mixotrophic species is thought to result in an underestimation of carbon fixation by over $50 \%$ (Stoecker \& Michaels 1991); thus assimilation ratios may actually be in the same range as for Mesodinium.

In our experiments, we found that Mesodinium, although not at 'red-water' densities, can sometimes make an important contribution to chlorophyll content and community rates of photosynthesis (Table 5). In Perch Pond on the morning of 6 October, Mesodinium was the dominant phytoplankter near the surface. Our calculations suggest that it contributed more chlorophyll than was measured in the bulk sample (Table 5). We suspect that this discrepancy is due to an underestimation of total chlorophyll when ciliates are a component of the photosynthetic assemblage (Putt 1990b). We used GF/F glass-fiber filters in our determinations of total chlorophyll; particulate chlorophyll is not in all cases retained quantitatively on filters (Phinney \& Yentsch 1985). Filtration can rupture Mesodinium (Smith \& Barber 1979) and many other planktonic ciliates (Gifford 1985). Cell rupture releases free plastids which may not be retained by glass-fiber filters. When plastidic ciliates are an important component of the plankton, whole water extraction methods (Phinney \& Yentsch 1985) may give better estimates of total chlorophyll than methods that rely on filtration (Putt 1990b). In our study, it is likely that underestimation of total chlorophyll in Expts II and III resulted in an overestimation of community chlorophyll-specific rates of photosynthesis (Table 3). This problem of cell rupture may also lead to biases in the estimation of chlorophyll-specific rates in studies of community photosynthesis during Mesodinium red-waters (discussed in Crawford 1989).

The contribution of Mesodinium to community primary production is difficult to evaluate since Mesodinium migrates vertically and forms patches near the surface in the morning (Smith \& Barber 1979) and, like other phytoplankton, may show diel changes in photosynthetic capacity (Prézelin et al. 1986). In the shallow estuaries in which we sampled, distribution problems were probably less than in open ocean studies, but the time and depth at which we collected the samples were biased in favor of maximal densities of this ciliate. However, it is clear that even under non-red-water conditions Mesodinium can, at times, make an important contribution to primary production in estuaries (Table 5).

The contribution of Mesodinium to community primary production has been estimated for samples collected on Georges Bank, Northwest Atlantic (Stoecker et al. 1989). Mesodinium occurred in surface waters at densities of $10^{2}$ to $10^{3}$ cells $1^{-1}$ as part of a rich microplankton assemblage. Single cell estimates of photosynthesis by Mesodinium indicated that at an irradiance of $100 \mu \mathrm{E} \mathrm{m}^{-2} \mathrm{~s}^{-1}$, this ciliate could account for 8 to $32 \%$ by the $\geq 20 \mu \mathrm{m}$ size fraction and $<1$ to $6 \%$ of total photosynthesis in surface water samples (calculated from data in Tables 6 \& 8 of Stoecker et al. 1989).

Estimates of the contribution of Mesodinium to primary production have been made for other areas and times based upon cell density, temperature and theoretical growth. For the Gulf of Maine near the Isles of Shoals (Northwest Atlantic), Montagnes \& Lynn (1989) have estimated that Mesodinium contributes $0.3 \%$ of the annual production. For the open, northern Baltic during spring, Leppänen \& Bruun (1986) esti-

Table 5. Estimated percent contribution of Mesodinium rubrum to chlorophyll a and primary production in the surface water samples

\begin{tabular}{|c|c|c|c|c|c|}
\hline $\begin{array}{l}\text { Expt } \\
\text { no. }\end{array}$ & Date & Location & Total chl a & Chl $a \geq 20 \mu \mathrm{m}$ & $\begin{array}{c}\text { Total primary } \\
\text { production }\end{array}$ \\
\hline I & 16 Jun 1988 & Perch Pond & $0.3 \%$ & $0.4 \%$ & $0.4 \%{ }^{a}$ \\
\hline II & 9 Jun 1989 & Salt Pond & $18 \%$ & $44 \%$ & $8 \%^{a}$ \\
\hline III & 6 Oct 1989 & Perch Pond & $\sim 135 \%$ & - & $73 \% b$ \\
\hline
\end{tabular}


mated that Mesodinium contributed about $10 \%$ of the primary production

Although estimates of the abundance and contribution of Mesodinium to the phytoplankton vary widely, it is clear that the importance of Mesodinium as a 'phytoplankter' is not limited to red-water conditions. This ciliate can be a dominant member of the microphytoplankton under more routine conditions. Cellspecific rates indicate that the photosynthetic physiology in this species during non red-water conditions may be similar in many respects to its physiology during red-water conditions. During both red-water and non-red-water conditions, Mesodinium can exhibit very high per unit cell volume and per unit chlorophyll rates of photosynthesis. The high volume-specific rates should be reflected in high growth rates. Its ability to accumulate near the sea surface and to photosynthesize at near maximum rates at high light intensities can give it an advantage over many other phytoplankters. In addition, its rapid swimming behavior appears to reduce its suspectibility to grazing (Jonsson \& Tiselius 1990) and may increase its ability to utilize nutrient micropatches (Gallager pers. comm.). The unique combination of its $\mathrm{P}-\mathrm{I}$ characteristics and behavior undoubtly contribute to its importance as a member of the microphytoplankton and its ability to form redwater blooms.

Acknowledgements. We thank Dr Carl A. Price for advice and assistance in application of the Percoll-sorbitol centrifugation technique to ciliates, and Mr David Russell, Mr Derek Hillis and Ms Stephanie Clendennen for help with field sampling. Dr John Spiesberger consulted on analysis of P-I curves. This research was supported by NSF grants OCE-8709961 and OCE-8800684 to DKS and a post-doctoral scholarship from the Natural Sciences and Engineering Research Council of Canada to MP. This is Contribution no. 7570 from the Woods Hole Oceanographic Institution.

\section{LITERATURE CITED}

Cabeçadas, G., Cunha, M. E., Moita, M. T., Pissarra, J., Sampayo, M. A. (1983). Red tide in Cascais Bay, Portugal. Bol. Inst. Nac. Invest. Pescas 10: 81-123

Crawford, D. W. (1989). Mesodinium rubrum: the phytoplankter that wasn't. Mar. Ecol. Prog. Ser. 58: 161-174

Edler, L. (ed.) (1979). Recommendations on methods for marine biological studies in the Baltic Sea - Phytoplankton and chlorophyll. The Baltic Marine Biologists Publ. No. 5, National Swedish Environment Protection Board, 38 pp.

Gieskes, W. W. C., Kraay, G. W. (1983). Dominance of Cryptophyceae during the phytoplankton spring bloom in the central North Sea detected by HPLC analysis of pigments. Mar. Biol. 75: 179-185

Gifford, D. J. (1985). Laboratory culture of marine planktonic oligotrichs (Ciliophora, Oligotrichida). Mar. Ecol. Prog Ser. 23: $257-267$

Glibert, P. M, Kana, T M., Anderson, D. M. (1988). Photosynthetic response of Gonyaulax tamarensis during growth in a natural bloom and in batch culture. Mar. Ecol. Prog. Ser. 42: 303-309

Glover, H. E. (1980). Assimilation numbers in cultures of marine phytoplankton. J. Plankton Res. 2: 69-79

Hasle, G. R. (1978). The inverted microscope method. In: Sournia, A. (ed.) Phytoplankton manual, Monogr. Oceanogr. Methods, 6, UNESCO, Paris, p. 88-96

Jassby, A., Platt, T (1976) Mathematical formulation of the relationship between photosynthesis and light for phytoplankton. Limnol. Oceanogr. 21: 540-547

Jonsson, P. R., Tiselius, P. (1990). Feeding behaviour, prey detection and capture efficiency of the copepod Acartia tonsa feeding on planktonic ciliates. Mar Ecol. Prog. Ser 60: $35-44$

Leppänen, J.-M., Bruun, J.-E. (1986). The role of pelagic ciliates including the autotrophic Mesodinium rubrum during the spring bloom of 1982 in the open northern Baltic proper. Ophelia, Suppl. 4: 147-157

Lindholm, T (1982). EDTA and oxalic acid - two useful agents for narcotizing fragile and rapid microzooplankton. Hydrobiologia 86: 297-298

Lindholm, T. (1985). Mesodinium rubrum - a unique photosynthetic ciliate. Adv. aquat. Microbiol 3: 1-48

Lindholm. T., Mörk, A.-C. (1990). Depth maxima of Mesodinium rubrum (Lohmann) Hamburger \& Buddenbrock - Examples from a stratified Baltic Sea inlet. Sarsia 75: $53-64$

Malone, T (1980). Algal size. In: Morris, I. (ed.) The physiological ecology of phytoplankton. University of California Press, Berkeley, p. 433-463

Montagnes, D. J. S., Lynn, D. H. (1989). The annual cycle of Mesodinium rubrum in the waters surrounding the Isles of Shoals, Gulf of Maine. J. Plankton Res. 11. 193-201

Packard, T. T., Blasco, D., Barber, R. T (1978). Mesodinium rubrum in the Baja California Upwelling System. In: Boje, R., Tomczak, M. (eds.) Upwelling ecosystems. SpringerVerlag, New York, p. 73-89

Parsons, T R., Blackbourn, D. J. (1968). Pigments of the ciliate Meosdinium rubrum (Lohmann). Neth. J. Sea Res. 4: 27-31

Parsons, T R., Maita, Y., Lalli, C. M. (1984). A manual of chemical and biological methods for seawater analysis. Pergamon Press, Oxford

Phinney, D. A., Yentsch, C. S. (1985). A novel phytoplankton chlorophyll extraction technique: toward automated analysis. J. Plankton Res. 7: 633-642

Platt, T., Gallegos, C. L., Harrison, W. G. (1980). Photoinhibition of photosynthesis in natural assemblages of marine phytoplankton. J. mar Res. 38: 687-701

Press, W. H., Flannery, B. P., Teukolsky, S. A., Vettering, W. T (1988). Numerical recipes in C: the art of scientific computing. Cambridge University Press, Cambridge

Prézelin, B. B., Putt, M., Glover, H. E. (1986). Diurnal patterns in photosynthetic capacity and depth-dependent photosynthesis irradiance relationships in Synechococcus spp. and larger phytoplankton in three water masses in the Northwest Atlantic Ocean. Mar. Biol. 91: 205-217

Price, C. A., Reardon, E. M., Guillard, R. R. L. (1978). Collection of dinoflagellates and other marine microalgae by centrifugation in density gradients of a modified silica sol. Limnol. Oceanogr. 23: 548-553

Putt, M. (1990a). Metabolism of photosynthate in the chloroplast-retaining ciliate Laboea strobila. Mar. Ecol. Prog. Ser. $60: 271-282$

Putt, M. (1990b). Abundance, chlorophyll content and photosynthetic rates of ciliates in the Nordic Seas during summer. Deep Sea Res. 37: 1713-1731

Putt, M., Stoecker, D. K. (1989). An experimentally deter- 
mined carbon:volume ratio for marine 'oligotrichous ciliates from estuarine and coastal waters. Limnol Oceanogr. 34: 1097-1103

Smith, W O. Jr, Barber, R. T (1979). A carbon budget for the autotrophic ciliate Mesodinium rubrum. J. Phycol. 15: 27-33

Stoecker, D. K, Michaels, A. E. (1991). Respiration, photosynthesis and carbon metabolism in planktonic ciliates. Mar. Biol. 108: 441-447

Stoecker, D. K., Taniguchi, A., Michaels, A. E. (1989). Abundance of autotrophic, mixotrophic and heterotrophic planktonic ciliates in shelf and slope waters. Mar. Ecol. Prog. Ser. 50: 241-254

Stoecker, D. K., Silver, M. W., Michaels, A. E., Davis, L. H (1988). Obligate mixotrophy in Laboea strobila, a ciliate which retains chloroplasts. Mar Biol. 99: 415-423

Stoecker, D. K., Silver, M. W., Michaels, A. E., Davis, L. H.

This article was submitted to the editor
(1988/1989). Enslavement of algal chloroplasts by four Strombidium spp. (Ciliophora, Oligotrichida) Mar. Microb. Food Webs 3: 79-100

Taylor, F. J. R., Blackbourn, D. J., Blackbourn, J. (1971). The red-water ciliate Mesodinium rubrum and its incomplete symbionts': a review including new ultrastructural observations. J. Fish. Res. Bd Can. 28: 391-407

Watras, C. J., Garcon, V. C., Olson, R. J., Chisholm, S. W., Anderson, D. M. (1985). The effect of zooplankton grazing on estuarine blooms of the toxic dinoflagellate Gonyaulax tamarensis. J. Plankton Res. 7: 891-908

Wilkerson, F. P., Grunseich, G. (1990). Formation of blooms by the symbiotic ciliate Mesodinium rubrum: the significance of nitrogen uptake. J. Plankton Res. 12: 973-989

Zar, J. H. (1974). Biostatistical analysis. Prentice-Hall, New Jersey

Manuscript frist received: November 28, 1990

Revised version accepted: April 9, 1991 